\section{LINGUISTIC LANDSCAPES OF BANGKOK}

\section{Thom Huebner ${ }^{1}$ and the \\ Graduate Students at Chulalongkorn University ${ }^{2}$}

\begin{abstract}
The effects of globalization of the world economy on English, now the dominant world language, has been well documented. While increasing attention has been paid to its changing form and to issues of identity and power (Phillipson 1992, Pennycook 1994,1998, Fishman et al. 1996, McArthur 1998, Bex and Watts 1999, etc.), less attention has been paid to the effects of globalization on the use of other
\end{abstract}

\footnotetext{
'Professor and Chair, Department of Linguistics and Language Development, San Jose State University, Washington Square, San Jose, CA 95192-0093

${ }^{2}$ The students who contributed to the research reported here include Achariya Rungnirundorn, Chitchon Pratontep, Chomrat Patanasorn, Kamlaitip Pattapong, Lalida Supatakulrat, Nantana Keksophawannakul, Pajaree Pipatchukiat, Saraporn Kunawatsatit, Shigeko Shimazu, Sudthida Pavavijarn, Suntaree Wannapairo, Tavicha Phadvibulya, Wanalee Mee-On, and Wannana Soontornnaruerangsee from the Program in Englis $h$ as an International Language, and Bussaya Chutikachorn, Luksanawadee Boonmee, Narumon Kittikullachart, Orapat Pookawes, Ornprapat Suwantaratip, Pensinee Kijkar, Penchan Panruek, Piroh Sriputtanatadakul, Sasithorn Sinthawornkul, Sunanta Wilaisilp, Therese Meedej, and Wilasinee Darachai from the Department of Linguistics.
}

languages for wider communication, particularly in large cosmopolitan urban areas in expanding circle countries. The current paper examines over 600 signs found in fifteen Bangkok "neighborhoods" to explore how the use of language in environmental print distinguishes one area of the city from another, and how English may be influencing the varieties of Thai in Bangkok.

\section{Introduction}

Globalization and Language: The effects of globalization of the world economy on English, now recognized as the dominant world language, has been well documented since the seminal work of scholars such as Fishman et al. 1977, Bailey and Görlach 1982, Smith 1983, Platt et al. 1984, and Kachru 1985. Professional journals such as World Englishes, English World-Wide, English Today, and Asian Englishes, and professional organizations such as the International Association for World Englishes (IAWL) have provided outlets for continued research and discussion on the topic.

In recent years, the discussion around English as a world language has expanded in at least two directions. First, there has been increasing attention to the politics of English as a world language and issues of identity and power (Phillipson 1992, Pennycook 1994,1998, Fishman et al. 1996, McArthur 1998, Bex and Watts 1999, etc.). Second, research has expanded from a focus on what Kachru (1992) calls the "outer circle," where English is taught as a second language (usually in post-colonial countries of Africa, South Asia, and Southeast Asia), to the "expanding circle," where English is 


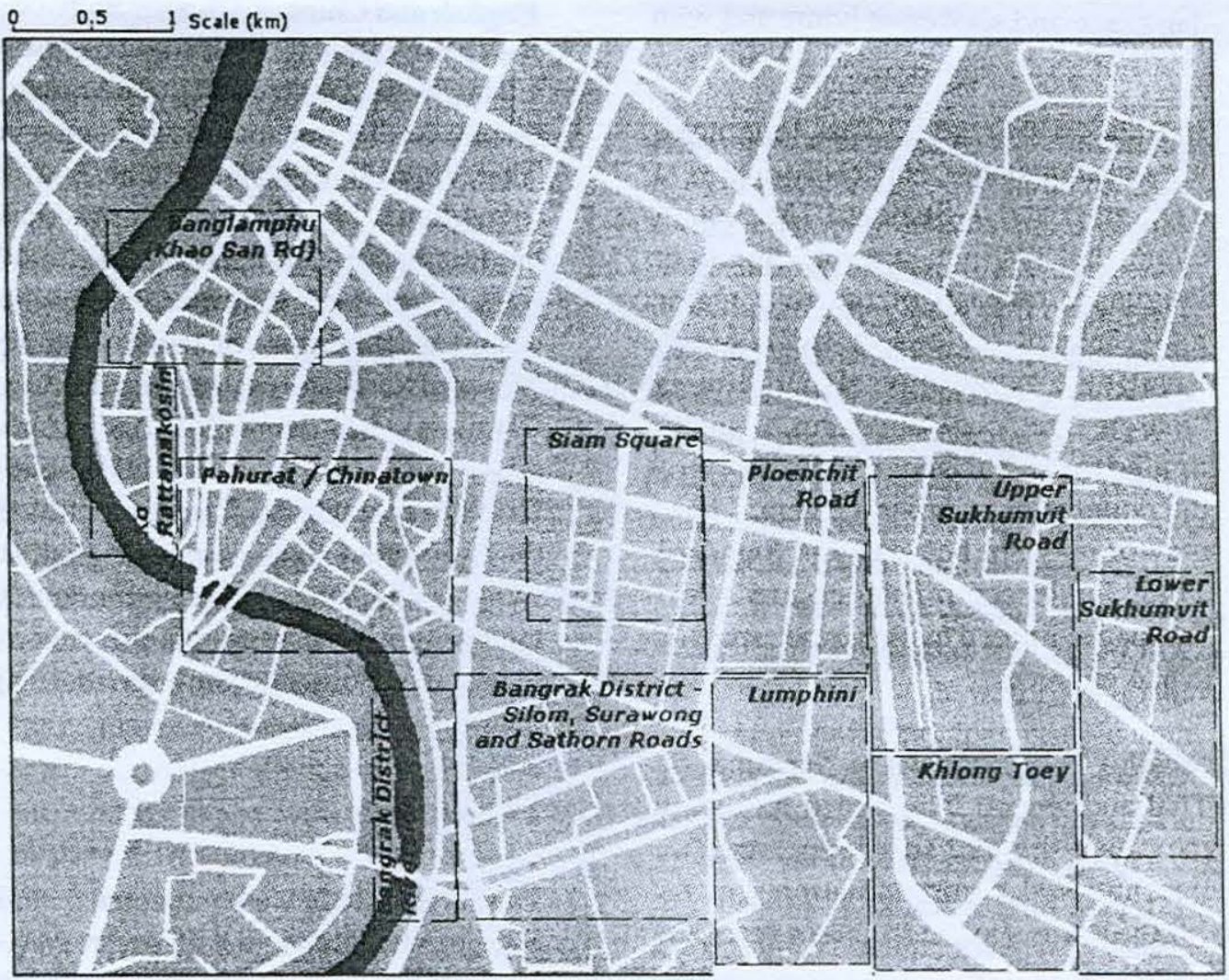

Map 1 (http://www.into-asia.com/bangkok/maps/)

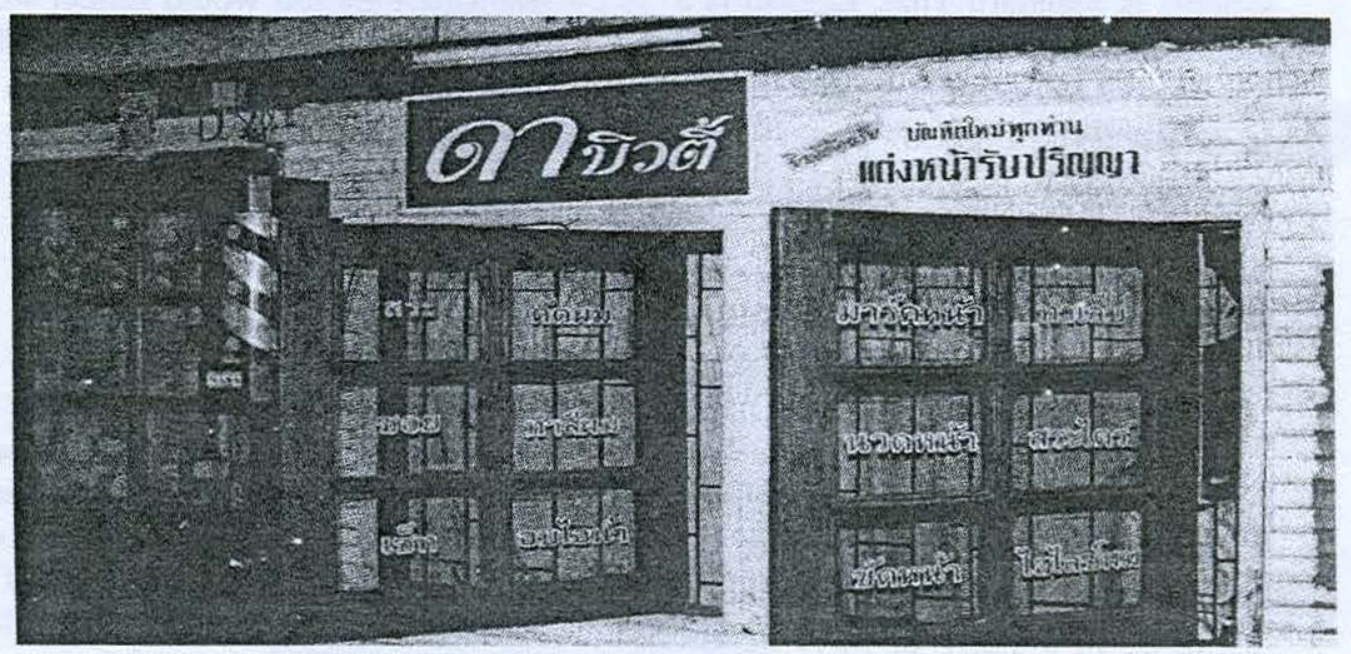

Picture 1 


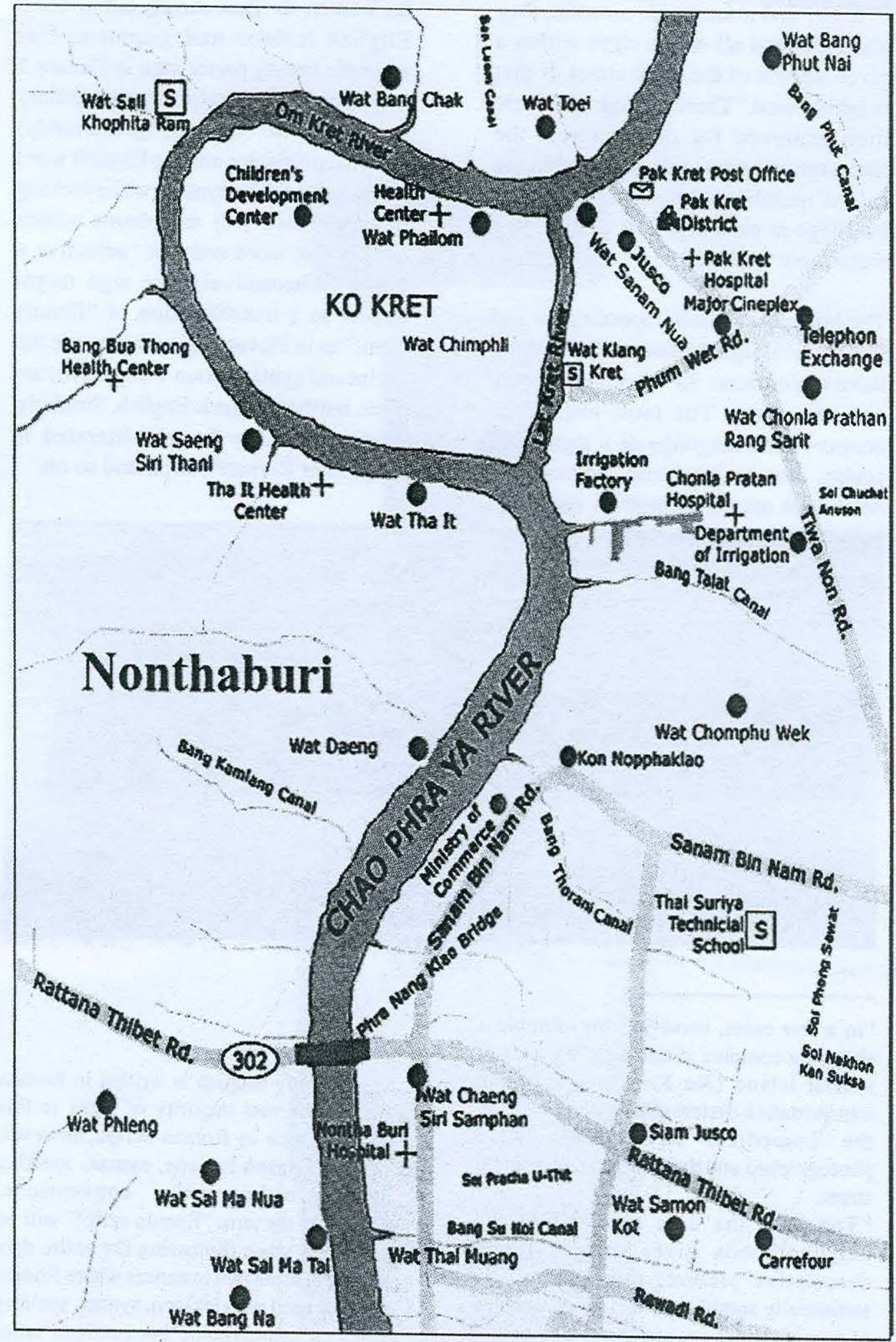

Map 2 (http://www.thailandmaps.net/nonthaburi/nonthaburi_map.html) 
In teams and armed with cameras, they photographed all of the signs within a given stretch of the main street of that neighborhood. ${ }^{4}$ These photographs were then analyzed for their source, the language or languages used, and in the case of multilingual signs, the dominant language in each sign. ${ }^{5}$ A total of 613 signs were analyzed.

The language of both monolingual and multilingual signs can be analyzed along three dimensions: its script, its lexicon, and its syntax. The most immediate access to the language of a sign is its script. But lexicon and syntax may determine access as well. A sign may

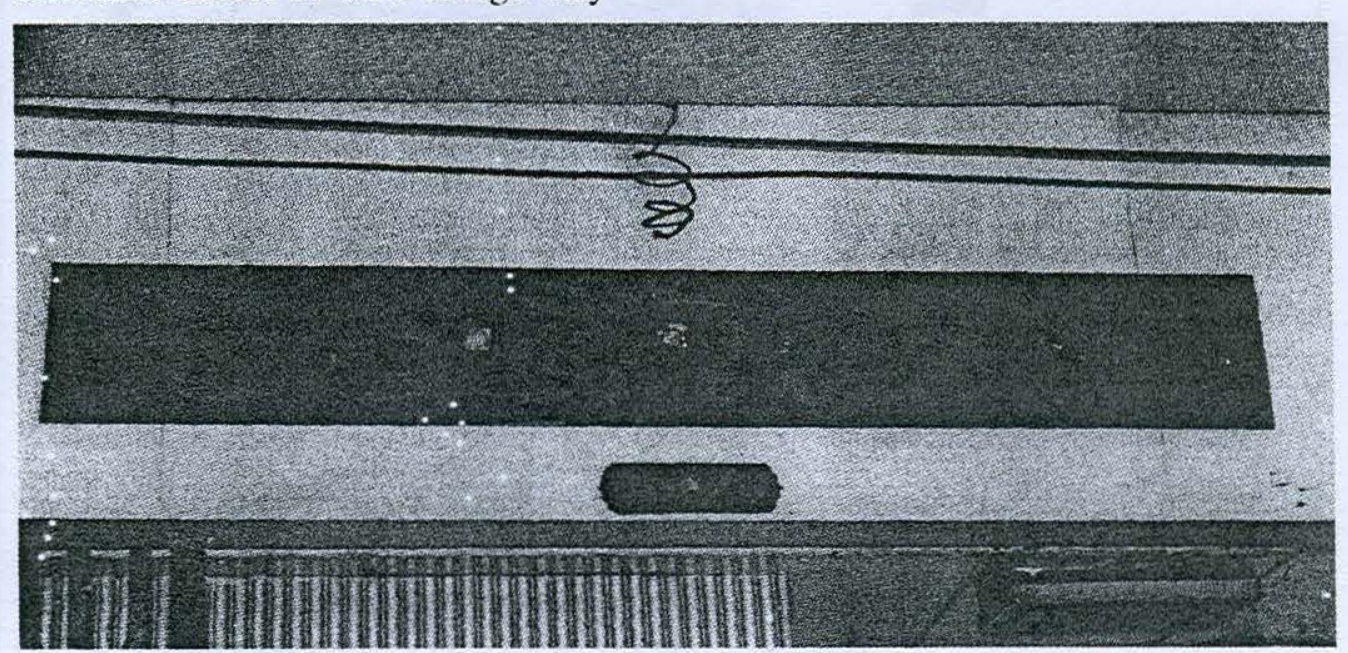

Picture 2

${ }^{4}$ In a few cases, involving for example a shopping complex (Siam Square), a small tourist island (Ko Kred), or a public transportation system (Sky Train), signs in the immediate environment were photographed and do not represent a single street.

${ }^{5}$ Together, the data from all of the neighborhoods gives only a rough descriptive picture, rather than any statistically significant relative dominance of any of the languages, since the number of signs analyzed in each neighborhood varies and is in part a reflection of the commercial nature of each. be written in Thai script, but contain English lexicon and grammar. For example beauty parlor sign in Picture 1 is written in Thai script; the vocabulary consists of the name of (presumably) the Thai proprietor and the English word "beauty." And the syntax, while lacking the possessive $\{-s\}$ morpheme retains the English word order of "adjective + noun." Alternatively, the sign might appear as a transliteration of "Beauty Ann," as in Picture 2, in which case the script and syntax (noun + adjective) are Thai, but the lexicon is English. Similarly, Thai words may be transliterated in English or Roman ${ }^{6}$ script, and so on. 
In a multilingual sign, one or more languages may be prominent. Prominence is established through a number of ways: placement of text, size of font, color of font, and amount of text.
Preferred placement of text is top or center. In languages that read from left to right, left is the preferred placement. The dominant language of the bilingual sign in Picture 3 , for example, is clearly Thai.

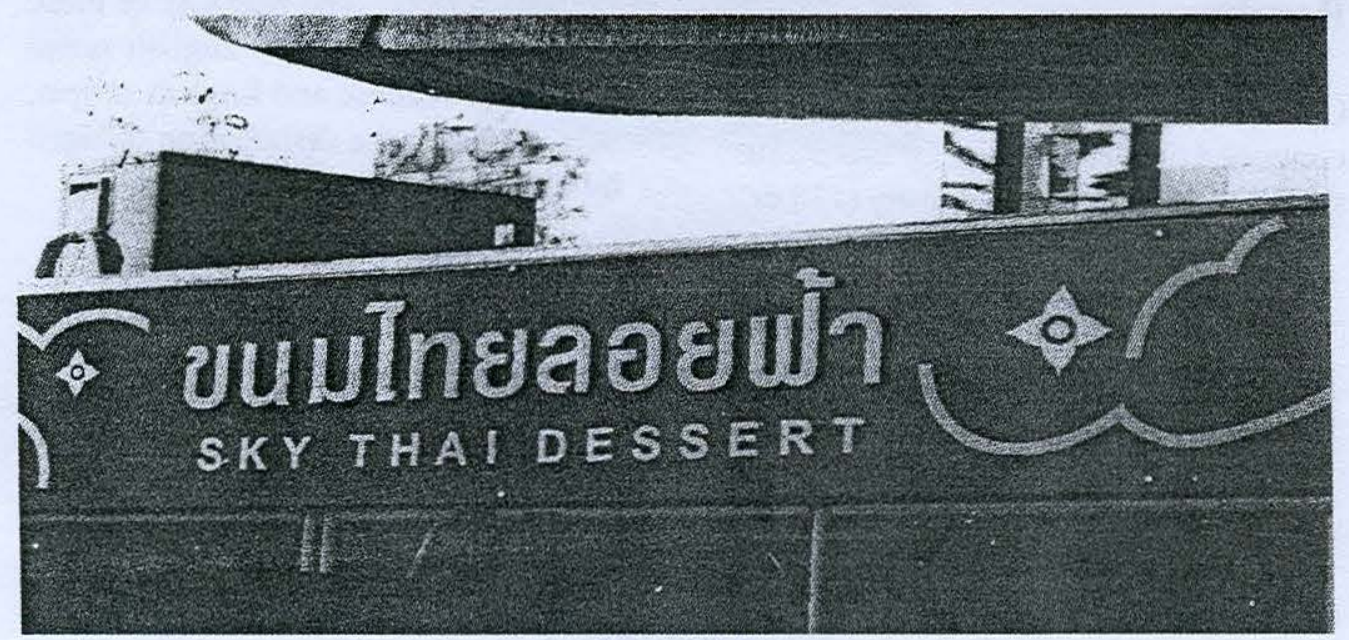

Picture 3

Placement of text may be offset, however, by a larger font size or by a color that foregrounds it. Finally, the amount of text may contribute to the prominence of one language over another in a given sign. In some cases, combinations of these features make it difficult to determine language dominance. For example, in the sign in Picture 4, the English script maintains the preferred position of upper and center. That it is written in red further adds to its prominence. But the Thai script text below it gives more information as to the nature of the business so that one could argue that Thai is the dominant language in this sign. However, the contents of the Thai script is a combination of English lexicon and Thai syntax: "Golf Center Lynx."

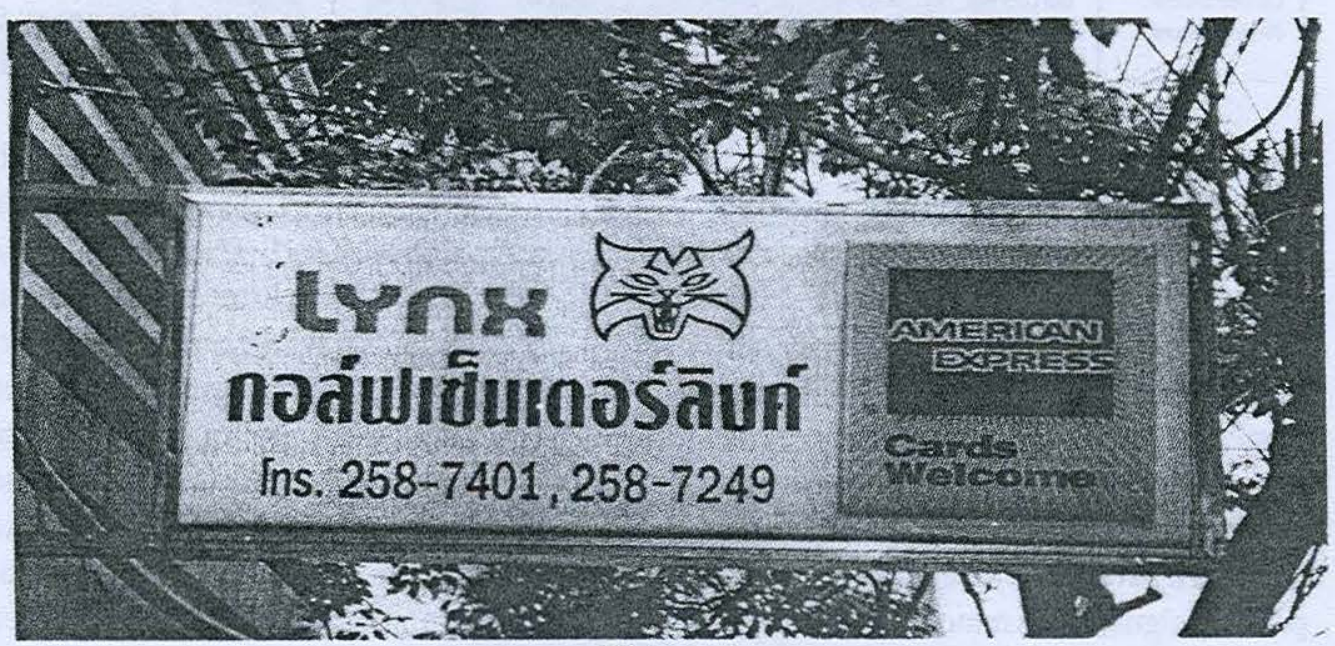

Picture 4 
Within a given neighborhood, the number of signs in a given language and the prominent language(s) of those signs provides some indication of the relative dominance of the languages found.

\section{Results}

Of the 613 signs examined, 276 or $45 \%$ contained only one script. Of these 276 single-script signs, the majority (158 or
57\%) were written in Thai script, with Roman script second (106 or $38 \%$ ). The remaining single-script signs were in Japanese (8), Arabic (3) and Chinese (1). However the majority of the signs in the data base ( 337 or $55 \%$ ) contain multiple scripts. The majority of these were either in Thai and English script or in Thai, Chinese and English scripts. Table 1 shows the distribution of signs by script from the entire corpus.

Table 1: Bangkok Signs by Script

\begin{tabular}{|c|c|c|c|c|c|c|c|}
\hline Script : & Thai & Roman & $\begin{array}{c}\text { Thai/ } \\
\text { Roman }\end{array}$ & $\begin{array}{c}\text { Thai/ } \\
\text { Roman/ } \\
\text { Chinese }\end{array}$ & $\begin{array}{c}\text { Thai/ } \\
\text { Chinese }\end{array}$ & Other & Totals \\
\hline Number (\%) & $158(26 \%)$ & $106(17 \%)$ & $203(33 \%)$ & $38(6 \%)$ & $17(3 \%)$ & $91(15 \%)$ & $613(100 \%)$ \\
\hline
\end{tabular}

\section{Government Signs}

Of the signs examined, 101 were produced by the government, either national, provincial, or municipal. (See Table 2.) Sixty of these, or nearly sixty percent, are monolingual in Thai, while thirty-four are in Thai and English. This reflects the official Thai government policy of Thai as the official national language and English as the official language of wider communication internationally.

Table 2: Bangkok Signs by Script and Source (Government vs. Non-government)

\begin{tabular}{|l|c|c|c|c|c|c|c|}
\hline Script Source & Thai & Roman & $\begin{array}{c}\text { Thai / } \\
\text { Roman }\end{array}$ & $\begin{array}{c}\text { Thai/ } \\
\text { Roman/ } \\
\text { Chinese }\end{array}$ & $\begin{array}{c}\text { Thai/ } \\
\text { Chinese }\end{array}$ & Other & Totals \\
\hline TOTAL & $158(26 \%)$ & $106(17 \%)$ & $203(33 \%)$ & $38(6 \%)$ & $17(3 \%)$ & $91(15 \%)$ & $613(100 \%)$ \\
Government & $60(59 \%)$ & $3(3 \%)$ & $34(34 \%)$ & $1(1 \%)$ & $1(1 \%)$ & $2(2 \%)$ & $101(100 \%)$ \\
Non-govern. & $98(19 \%)$ & $103(20 \%)$ & $169(33 \%)$ & $37(7 \%)$ & $16(3 \%)$ & $89(18 \%)$ & $512(100 \%)$ \\
\hline
\end{tabular}

Among government signs (Table 3), there is little variation across neighborhoods in Bangkok. At the national level, signs announcing the names of national ministries or institutions tend to be in Thai and English. This is also true of street signs and traffic signs giving directions to neighboring towns or neighborhoods. Signs regulating traffic, such as no parking signs, signs announcing one way streets or no left turns, on the other hand, tend to be written in Thai only, regardless of the neighborhood. The same is true for signs forbidding littering, digging in the street, selling wares on the sidewalk, and the like. Signs announcing police stations tend to be monolingual in Thai in traditionally Thai neighborhoods, and are more likely to be bilingual Thai and English in newer commercial neighborhoods, and in areas considered tourist attractions. 
Table 3: Type of Script, Government Signs by Neighborhood

\begin{tabular}{|l|c|c|c|c|c|c|c|}
\hline $\begin{array}{c}\text { Script } \\
\text { Neighborhood }\end{array}$ & Thai & English & $\begin{array}{c}\text { Thai/ } \\
\text { English }\end{array}$ & $\begin{array}{c}\text { Thai/ } \\
\text { English/ } \\
\text { Chinese }\end{array}$ & $\begin{array}{c}\text { Thai/ } \\
\text { Chinese }\end{array}$ & Other & Totals \\
\hline 1 Pathumthani & $6(75 \%)$ & & $2(25 \%)$ & & & & $8(100 \%)$ \\
\hline 2 Thanon Phichai & $8(80 \%)$ & & $2(20 \%)$ & & & & $10(100 \%)$ \\
\hline 3 Saphaan Han & $10(67 \%)$ & & $5(33 \%)$ & & & & $15(100 \%)$ \\
\hline 4 Koh Krerd & $3(30 \%)$ & & $5(50 \%)$ & & & $2(20 \%)$ & $10(100 \%)$ \\
\hline 5 Henri Dunant & $7(50 \%)$ & & $7(50 \%)$ & & & & $14(100 \%)$ \\
\hline 6 Phra Athit & $5(56 \%)$ & & $4(44 \%)$ & & & & $9(100 \%)$ \\
\hline 7 Charoen Krung & $2(67 \%)$ & & $1(33 \%)$ & & & & $3(100 \%)$ \\
\hline 8 Yawarat & $4(57 \%)$ & $1(14 \%)$ & $2(29 \%)$ & & & & $7(100 \%)$ \\
\hline *Siam Square & & & & & & & \\
\hline 10 Sukhumvit & $2(100 \%)$ & & & & & & $2(100 \%)$ \\
\hline 11 Sky Train & $1(25 \%)$ & & $3(75 \%)$ & & & & $4(100 \%)$ \\
\hline 12 Khao Saan & $8(67 \%)$ & $2(17 \%)$ & $1(8 \%)$ & $1(8 \%)$ & & & $12(100 \%)$ \\
\hline 13*Thong Law & & & & & & & \\
\hline 14 Thaniya & & & $2(100 \%)$ & & & & $2(100 \%)$ \\
\hline 15 Soi Nana & $5(100 \%)$ & & & & & & $5(100 \%)$ \\
\hline TOTALS & $60(60 \%)$ & $3(3 \%)$ & $34(34 \%)$ & $1(1 \%)$ & $0(0 \%)$ & $2(2 \%)$ & $101(100 \%)$ \\
\hline
\end{tabular}

*No government signs were found in the corpus from Siam Square and Thong Law.

An interesting variation from this pattern can be found on Koh Kred, an island on the outskirts of the city which the local residents together with the Thai Tourist Organization are promoting as a tourist destination. One of its attractions is the fact that it is an old Mon settlement and the traditional residents have worked to preserve their minority language and distinctive crafts, especially a type of pottery. It is the only example in the data in which the government has used a minority language (Mon) on official signs to announce government offices.

\section{Non-Government Signs}

In contrast to the signs posted by the government, signs posted by the private sector show considerable variation across neighborhoods. The fifteen neighborhoods display five patterns of language use in commercial signs: a) neighborhoods with predominantly Thai monolingual signs; $b$ ) neighborhoods with a balance between monolingual Thai and bi-lingual Thai-English signs; c) neighborhoods with predominantly ThaiChinese multilingual signs; d) neighborhoods with predominantly Thai-English bilingual signs; and e) neighborhoods with a preponderance of commercial signs in a language or languages other than Thai.

\section{a) Predominantly Thai Monolingual Sign Neighborhoods}

Three neighborhoods were found to have predominantly Thai monolingual commercial signs:Thanon Pichai, Pathumthani, and Koh Kred (see Table 4). 
Table 4: Predominantly Thai Monolingual Sign Neighborhoods

\begin{tabular}{|l|c|c|c|c|c|c|c|}
\hline $\begin{array}{c}\text { Script } \\
\text { Neighborhood }\end{array}$ & Thai & English & $\begin{array}{c}\text { Thai/ } \\
\text { English }\end{array}$ & $\begin{array}{c}\text { Thai/ } \\
\text { English/ } \\
\text { Chinese }\end{array}$ & $\begin{array}{c}\text { Thai/ } \\
\text { Chinese }\end{array}$ & Other & Totals \\
\hline 1 Pathumthani & $6(75 \%)$ & & $2(25 \%)$ & & & & $8(100 \%)$ \\
\hline 2 Thanon Phichai & $8(80 \%)$ & & $2(20 \%)$ & & & & $10(100 \%)$ \\
\hline 3 Saphaan Han & $10(67 \%)$ & & $5(33 \%)$ & & & & $15(100 \%)$ \\
\hline 4 Koh Krerd & $3(30 \%)$ & & $5(50 \%)$ & & & $2(20 \%)$ & $10(100 \%)$ \\
\hline 5 Henri Dunant & $7(50 \%)$ & & $7(50 \%)$ & & & & $14(100 \%)$ \\
\hline 6 Phra Athit & $5(56 \%)$ & & $4(44 \%)$ & & & & $9(100 \%)$ \\
\hline 7 Charoen Krung & $2(67 \%)$ & & $1(33 \%)$ & & & & $3(100 \%)$ \\
\hline 8 Yawarat & $4(57 \%)$ & $1(14 \%)$ & $2(29 \%)$ & & & & $7(100 \%)$ \\
\hline \% Siam Square & & & & & & & \\
\hline 10 Sukhumvit & $2(100 \%)$ & & & & & & $2(100 \%)$ \\
\hline 11 Sky Train & $1(25 \%)$ & & $3(75 \%)$ & & & & $4(100 \%)$ \\
\hline 12 Khao Saan & $8(67 \%)$ & $2(17 \%)$ & $1(8 \%)$ & $1(8 \%)$ & & & $12(100 \%)$ \\
\hline 13*Thong Law & & & & & & & \\
\hline 14 Thaniya & & & $2(100 \%)$ & & & & $2(100 \%)$ \\
\hline 15 Soi Nana & $5(100 \%)$ & & & & & & $5(100 \%)$ \\
\hline TOTALS & $60(60 \%)$ & $3(3 \%)$ & $34(34 \%)$ & $1(1 \%)$ & $0(0 \%)$ & $2(2 \%)$ & $101(100 \%)$ \\
\hline
\end{tabular}

Thanon Phichai is in a neighborhood near the Parliament Building and the Residential Palace of His Majesty the King. The neighborhood contains housing for many of the middle level government workers. The commercial signs examined on this street were primarily for small businesses, in particular service enterprises such as auto repair shops, beauty and barber shops, pawn shops, law offices and the like. Only two restaurants were found in this sub-sample. That one was called the "Fishy Fish Restaurant" suggests that the use of English on this sign is intended to convey a cosmopolitan air rather than to attract an international audience.

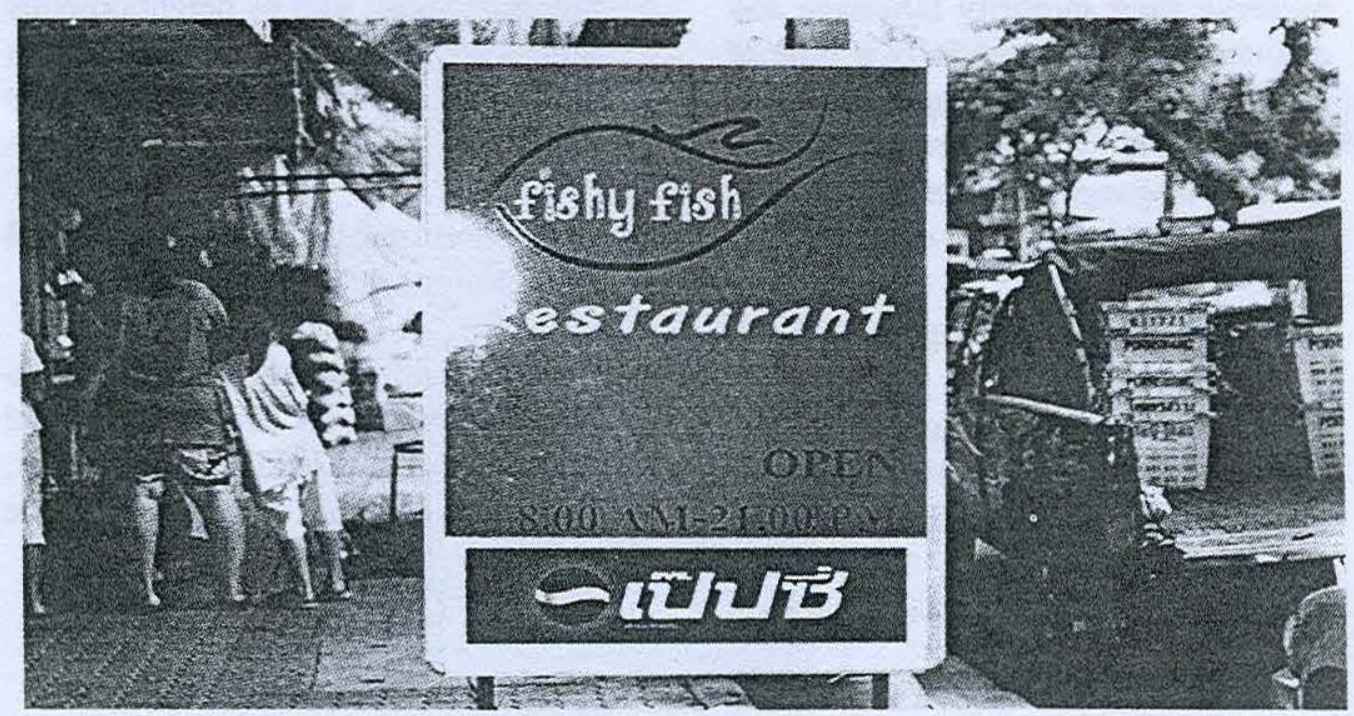

Picture 5 
Pathumthani was once considered a province quite apart from the capital city, but with the advent of urban sprawl has become a commuter bedroom community for many middle and working class Thais employed in the city. The commercial signage here is for retail businesses such as appliance, auto supply, electronics and drug stores, as well as for services such as financial institutions, private schools and medical clinics. A number of signs, all entirely in Thai, advertise real estate for sale.

Both Thanon Pichai and Pathumthani are considered "off the beaten path" of tourists to the city. As such, the ThaiRoman (all English) script signs found here are for international brands. It might be hypothesized that both might most closely reflect the language patterns of commercial signs in nontourist up-country towns.
In contrast, Koh Krerd is a tourist destination, with the bulk of the signs advertising souvenir shops, restaurants, and points of interest. To date Koh Krerd had attracted a primarily local Thai following. Nevertheless, the use of English on signs in this neighborhood is clearly directed toward the prospective international tourist.

\section{b) Neighborhoods with a Balance of Thai Monolingual and Thai- English Bilingual Signs}

Two neighborhoods, Phra Athit Road and Henri Dunant Road, display an even distribution of commercial signs in monolingual Thai and in Thai and English. In addition to similar language use patterns, these two neighborhoods both are home to a large proportion of government and non-government institutions and have relatively few commercial enterprises. Table 5 shows the distribution of non-government signs in each of these two neighborhoods.

Table 5: Neighborhcods with a Balance of Thai Monolingual and Thai/English Bilingual Signs

\begin{tabular}{|l|c|c|c|c|c|c|c|}
\hline $\begin{array}{c}\text { Script/ } \\
\text { Neighborhood }\end{array}$ & Thai & English & $\begin{array}{c}\text { Thai/ } \\
\text { English }\end{array}$ & $\begin{array}{c}\text { Thai/ } \\
\text { English/ } \\
\text { Chinese }\end{array}$ & $\begin{array}{c}\text { Thai/ } \\
\text { Chinese }\end{array}$ & Other & Totals \\
\hline Henri Dunont & $6(46 \%)$ & $1(8 \%)$ & $6(46 \%)$ & & & & $13(100 \%)$ \\
\hline Phra Athit & $2(40 \%)$ & $1(20 \%)$ & $2(40 \%)$ & & & & $5(100 \%)$ \\
\hline TOTALS & $8(44 \%)$ & $2(12 \%)$ & $8(44 \%)$ & & & & $18(100 \%)$ \\
\hline
\end{tabular}

Phra Athit Road, near the original Royal Palace, the Temple of the Emerald Buddha and older government offices, follows the path of the old wall of the city and was developed around the turn of the century, when a number of members of the royal family built their palaces there (Askew 1994: 165). Many of these old palaces have become the home of religious and non-profit institutions under Royal patronage and buildings designated as historical landmarks. Signs associated with these institutions were analyzed as belonging to the government. The offices of the United Nations Food and Agriculture Organization, on the other hand, while non-commercial, were analyzed as nongovernment. Signage for this organization is both bilingual in Thai and English and monolingual in Thai. 
Henri Dunant Road runs along the back side of Chulalongkorn University and one of the most prestigious Thai preparatory schools. On the same street are the Bangkok Sports Club, a traditional institution of the Thai upper class, the Chulalongkorn University Hospital, and several other medical institutions. Many of these institutions were established in the first two decades of the twentieth century. There are few commercial establishments along this street, and the signs tend to advertise special educational programs and other services, as well as general international product advertisements apart from individual stores or shops.

The signs in these neighborhoods reflect government policy of Thai as a unifying national characteristic and bilingualism to accommodate foreigners and address role of Thailand as a member of the international community.

\section{c) Neighborhoods where Thai- Chinese Multilingual Signs Dominate}

Two neighborhoods in the sample display a relatively high proportion of Chinese language in the commercial signs found there (Table 6). Yawarat and Charoen Krung Roads both date back to the midnineteenth century (Bhamorabutr 1987: 37), a time when Chinese played a much larger part in the commercial life of the city than it does now. These two streets are still, however, home to some of the older businesses in Bangkok and their signs reflect this fact.

Table 6: Thai/Chinese Multilingual Sign Neighborhoods

\begin{tabular}{|l|c|c|c|c|c|c|c|}
\hline $\begin{array}{c}\text { Script/ } \\
\text { Neighborhood }\end{array}$ & Thai & English & $\begin{array}{c}\text { Thai / } \\
\text { English }\end{array}$ & $\begin{array}{c}\text { Thai/ } \\
\text { English/ } \\
\text { Chinese }\end{array}$ & $\begin{array}{c}\text { Thai/ } \\
\text { Chinese }\end{array}$ & $\begin{array}{c}\text { *Other: } \\
\text { C/E/J 4 } \\
\text { C 1 }\end{array}$ & Totals \\
\hline Charoen Krung & $7(26 \%)$ & $1(4 \%)$ & $4(15 \%)$ & $12(44 \%)$ & $3(11 \%)$ & & $27(100 \%)$ \\
\hline Yawarat & $2(8 \%)$ & & $1(4 \%)$ & $10(42 \%)$ & $6(25 \%)$ & $5(21 \%)$ & $24(100 \%)$ \\
\hline TOTALS & $9(18 \%)$ & $1(2 \%)$ & $5(10 \%)$ & $22(43 \%)$ & $9(18 \%)$ & $5(10 \%)$ & $51(100 \%)$ \\
\hline
\end{tabular}

The signs in the sub-sample for Yawarat Road are evenly divided among service businesses such as financial institutions, traditional massage parlors, pawn and printing shops on the one hand and retail businesses such as food, jewelry, and traditional medicine shops on the other. Only three restaurants and two small hotels are included in the sample. Charoen Krung differs only in the proportion and variety of retail shops, including electronics stores, construction and beauty supply stores, and furniture shops in addition to the goods and services found on Yawarat.
In both neighborhoods, Chinese continues to be an important language of commerce, but it is worth noting that only one of the 51 signs in this sample contains only Chinese. All other signs containing Chinese are either bilingual (Chinese - Thai) or multilingual, a reflection of the Bangkok Chinese willingness to assimilate to Thai language and culture (Askew 1994:44).

d) Neighborhoods in which ThaiEnglish Bilingual Signs are Dominant 
Table 7 lists those neighborhoods in which the majority of commercial signs were found to be bi- or multilingual in Thai and Roman scripts, all but one of the latter were in English. These neighborhoods include Saphaan Han, Siam Square, Sukhumvit Road and the Sky Train.

Table 7: Thai/English Bilingual Sign Neighborhoods

\begin{tabular}{|l|c|c|c|c|c|c|c|}
\hline $\begin{array}{c}\text { Script / } \\
\text { Neighborhood }\end{array}$ & Thai & English & $\begin{array}{c}\text { Thai / } \\
\text { Roman }\end{array}$ & $\begin{array}{c}\text { Thai / } \\
\text { English/ } \\
\text { Chinese }\end{array}$ & $\begin{array}{c}\text { Thai / } \\
\text { Chinese }\end{array}$ & $\begin{array}{c}\text { *Other: } \\
\text { T/E/U 2 } \\
\text { T/E/J 4 } \\
\text { E/J 2 }\end{array}$ & Totals \\
\hline Saphaan Han & $4(23 \%)$ & $2(12 \%)$ & $6(35 \%)$ & $3(18 \%)$ & & $2(12 \%)$ & $17(100 \%)$ \\
\hline Siam Square & $4(12 \%)$ & $5(15 \%)$ & $16(49 \%)$ & $2(6 \%)$ & $1(3 \%)$ & $5(15 \%)$ & $33(100 \%)$ \\
\hline Sukhumvit & $11(14 \%)$ & $10(13 \%)$ & $45(58 \%)$ & $8(10 \%)$ & $2(3 \%)$ & $1(1 \%)$ & $77(100 \%)$ \\
\hline Sky Train & $5(18 \%)$ & $6(21 \%)$ & $17(61 \%)$ & & & & $28(100 \%)$ \\
\hline TOTALS & $24(15 \%)$ & $23(15 \%)$ & $84(54 \%)$ & $13(8 \%)$ & $3(2 \%)$ & $8(5 \%)$ & $155(100 \%)$ \\
\hline
\end{tabular}

$* \mathrm{~T} / \mathrm{E} / \mathrm{U}=$ Thai $/$ English $/$ Urdu; T/E.J = Thai / English $/$ Japanese; E/J = English $/$ Japanese

The oldest of these neighborhoods is Saphaan Han. The name refers to a bridge dating back to the establishment of the city in the Eighteenth Century. The bridge has long since disappeared, but the neighborhood is still referred to by its name. The roads within the neighborhood were built during the same period as Yawarat and Charoen Krung, and like them, the commercial signs in this neighborhood are equally divided between local businesses providing financial, health, and travel services, for example, and goods such as clothing and house wares. Unlike the other two neighborhoods, however, there is considerably less Chinese used here.

Siam Square, a shopping district which appears on maps of the 1936 Plan of Bangkok (Sternstein 1986: 47), is located in the heart of what has since become one of the major commercial centers of Bangkok. It contains businesses

\footnotetext{
7 In this table, the term "Roman" is used, since one of the signs in Siam Square containing Roman script was in French.
}

providing services such as graphics shops, medical offices, beauty and barber shops, financial institutions, and private schools for dance and music, language, the trades, etc. More than any of the other neighborhoods discussed so far, Siam Square has a large proportion of its commercial space devoted to entertainment, particularly restaurants. It is also the first neighborhood discussed so far in which Roman script was found for a language other than English or a transliteration of Thai or Chinese. One bilingual Thai / Roman script sign was in Thai and French.

Sukhumvit Road, a thoroughfare connecting Bangkok and the country's eastern seaboard, also appears on the city's far eastern edge on the 1936 maps, but does not appear on the "List of Place Names to Accompany the Plan of Bangkok" (Sternstein 1986). Nor do the 1936 maps show any adjacent side streets, suggesting that while an important highway linking Bangkok to the country's eastern seaboard, Sukhumvit Road had not yet developed as a commercial area. That develop- 
ment began when middle class Thais moved from central Bangkok beginning in the 1950s, and was accelerated in the 1960 s, when foreigners also found the neighborhood (Askew 1994: 168). The vast majority of signs along this strip advertise and announce retail enterprises selling home furnishings, food, cloths, health and beauty products, photo and auto supplies, and the like Service enterprises such as banks, beauty salons, and travel agencies can also be found. Only one bar was found in the data.

Finally, the Sky Train is an elevated urban light rail system that spans 23 kilometers from Chatuchak Park on the north end of the city to Sukhumvit 77 in the southeast. Although the Sky Train is not a neighborhood per se, like physical neighborhoods, it caters to a subset of the Bangkok population, in this case its middle class, foreign resident and tourist populations. It has been a symbol of modernity since it's opening in December of 2000. The signs in this subset of the data are both from advertisements inside the cars themselves, and from advertisements and shops inside the stations. The majority of the signs advertise international products and services independent of individual local stores, but the stations also contain shops selling food, books, photo supplies, and the like. While many of these signs are bilingual and are aimed at both local and foreign riders, the use of language mixing suggests that the intended Thai audience is a very restricted one.

In each of these neighborhoods, the majority of signs examined are multilingual in Thai and English. With respect to the establishment of these commercial neighborhoods and the pattern of commercial signage in each, the more recent the commercial neighborhood, the more use of ThaiEnglish bilingual signs.

\section{e) Non-Thai Sign Dominant Neighborhoods}

Four neighborhoods in the study contain a majority of commercial signs in languages other than Thai (Table 8).

Table 8: Non-Thai Dominant Neighborhoods

\begin{tabular}{|c|c|c|c|c|c|c|c|}
\hline $\begin{array}{c}\text { Script / } \\
\text { Neighborhood }\end{array}$ & Thai & English & $\begin{array}{l}\text { Thai / } \\
\text { Roman? }\end{array}$ & $\begin{array}{l}\text { Thai / } \\
\text { English / } \\
\text { Chinese }\end{array}$ & $\begin{array}{l}\text { Thai / } \\
\text { Chinese }\end{array}$ & $\begin{array}{l}\text { *Other: } \\
\text { T/E/H/J 2 } \\
\text { T/E/J 2 } \\
\text { E/J 29 } \\
\text { J/T } 10 \\
\text { J } 8 \\
\text { T/A/E 13 } \\
\text { A/E 9 } \\
\text { A 3 }\end{array}$ & Totals \\
\hline Khao Saan & $3(6 \%)$ & $24(51 \%)$ & $17(36 \%)$ & & $1(2 \%)$ & $2(4 \%)$ & $47(100 \%)$ \\
\hline Thong Law & $1(2 \%)$ & $28(52 \%)$ & $12(25 \%)$ & $1(2 \%)$ & & $9(19 \%)$ & $51(100 \%)$ \\
\hline Thaniya & $4(7 \%)$ & $7(12 \%)$ & $7(12 \%)$ & $1(2 \%)$ & & $40(68 \%)$ & $59(100 \%)$ \\
\hline Soi Nana & $2(3 \%)$ & $16(24 \%)$ & $21(32 \%)$ & & $2(3 \%)$ & $25(38 \%)$ & $66(100 \%)$ \\
\hline TOTALS & $10(4 \%)$ & $75(34 \%)$ & $57(26 \%)$ & $2(1 \%)$ & $3(1 \%)$ & $76(34 \%)$ & $223(100 \%)$ \\
\hline
\end{tabular}

*T/E/H/J = Thai / English / Hebrew / Japanese; T/E.J = Thai / English / Japanese; E/ $\mathrm{J}=$ English $/ \mathrm{J}$ apanese; $\mathrm{J} / \mathrm{T}=\mathrm{Japanese} / \mathrm{Thai} ; \mathrm{J}=$ Japanese; T/A/E = Thai $/$ Arabic $/$ English; $\mathrm{A} / \mathrm{E}=$ Arabic $/$ English; $\mathrm{A}=$ Arabic 
The neighborhood of what is now Khao Saan Road was established in the 1880 s (Askew 1994: 164). In the 1970s and 1980 s it became a haven for European, American and Australian back-packers. Over the past few years, it has been promoted by the Tourist Authority of Thailand as a low-cost international travel destination, with a variety of restaurants and shops catering not only to back-packers but also to lower budget international travelers from all over. On Khao Saan Road, one can find any number of languages displayed, but the majority in this sample are English monolingual signs $(n=24)$. The commercial signs identified on Khao Saan Road reflect the tourist character of the neighborhood with 13 signs devoted to entertainment (three from bars, nine from restaurants, and one from a massage parlor); fourteen to service industries (two for health clinics, two for laundries, one for a barber, three for travel agencies, two for currency exchanges, one for taxi service, and three for prepared foods), and 20 for other retail businesses (six for jewelry stores, six for tailors, one for a souvenir shop, one for a photo shop, one for a health and beauty shop, and five for other dry goods stores. Only one sign in the sample advertised a product independent of a retail business on the street, that for a popular high energy drink.

Thong Law is a commercial street adjacent to a residential neighborhood that is the home of many foreign residents in the city. Again, while a variety of other languages are represented in the commercial signage (notably Japanese) monolingual English signs predominate. Over half of the signs in this subset of the data are devoted to services such as private schools for music, dance, language lessons and the like (9), banking (5), health and beauty (4), interior design, laundry, travel, and message (4). About a quarter are devoted to retail businesses selling such goods as jewelry, gifts, auto supplies, drugs, toys, clothes, books, and kitchen supplies. The remainder are for restaurants and hotels.

Thaniya Road is a short but very busy commercial road catering to Japanese businessmen. The majority of signs on this street are either monolingual Japanese $(n=8)$ or bilingual JapaneseEnglish $(n=22)$. A common alternative pattern is monolingual Japanese $(n=10)$ with a Thai translation or transliteration in very small print, usually in the upper right hand corner of the sign. The motivation for this is monitary: there are tax incentives for including Thai on commercial signs in Bangkok. In terms of the nature of the signs in this sub-set of the data, over half (32) are devoted to bars, six to restaurants, five to massage parlors, and the remaining to services (travel agencies, health clinics) or retail stores (convenience, jewelry, drug and book stores, for example). Of the four signs only in Thai, one announces no parking, one is advertising for a hostess at a night club, and one is for the health clinic.

Finally, Soi Nana contains a large percentage (38\%) of signs in Arabic $(n=3)$, Arabic and English $(n=9)$ or Arabic, English and Thai $(n=13)$. One Thai-Roman script sign in the data set was in Thai and French. In contrast to Thaniya Road, where there were bilingual signs in Thai and Japanese, the data set from Soi Nana contain no multilingual signs that did not include Roman script. There are no Thai-Arabic bilingual signs, for example. Half of the 
sub-sample for Soi Nana are for services such as health and beauty, finance, medical, dry cleaning, travel, telecommunication, and massage. The remainder are evenly divided between retail business advertising jewelry, clothes, perfumes, and food, and entertainment venues such as restaurants, bars, and hotels.

While these four neighborhoods share with each other the fact that the majority of signs in the sample were non-Thai dominant, each has a very distinct pattern of language use in its nongovernment commercial signage. Khao Saan Road displays a variety of languages, but English is by far the dominant language of commerce. Thong Law also displays heavy English language use, but with Japanese also found to a great extent. Thaniya Road is predominantly Japanese in its use of language in commercial signs, while Soi Nana has a preponderance of Arabic in addition to English.

\section{Discussion}

This study has examined the linguistic landscapes of fifteen neighborhoods in the Greater Bangkok area. In doing so, it highlights the importance and influence of English as a global language, a point that has been made in research on shop signs in other areas of the world (Schlick 2003, MacGregor 2003, McArthur 2000). At the same time, this study expands on that line of research in several ways. First an examination of the signs from government sources versus those from the private sector points up the discrepancy between official government language policy and the language use patterns practiced within the city's various communities and promoted by the commercial sector.
Second, a comparison of various neighborhoods within a given geographical area reveals the extent of linguistic diversity in a large metropolitan area like Bangkok. Third, a comparison of neighborhoods in terms of when they were established and the patterns of language use in each suggests a shift over time from Chinese to English as the major language of wider communication in the city.

The linguistic diversity revealed in this study is a reflection of the nature of each neighborhood, its inhabitants, and those it is intended to serve. The study of the linguistic landscapes of an urban area can provide a picture into the social structures, the power relations, and status of various languages within individual neighborhoods and the larger community. From a linguistic perspective, it raises important questions: What is the effect of the pervasiveness of English on the development of Thai? How is English affecting the phonology, orthography, lexicon, syntax and pragmatics of Thai? Conversely, is the pervasiveness of English leading to the eventual development of a nativized Thai variety of English? At a more theoretical level, it challenges time-honored linguistic notions. For example, it calls into question the boundaries of a speech community and even what constitutes a language itself. From a more applied perspective, it raises questions about the effects of the pervasiveness of English in the linguistic landscape of Bangkok on the language proficiency, both Thai and English, of its youngest citizens.

At a very practical level, the study of linguistic landscapes can provide a vehicle for introducing students of language into the nature of its structure and use. It can be a tangible tool for 
demonstrating the principles of research methodology. Finally, it can provide graduate students of language and linguistics with a myriad of important and researchable thesis and dissertation topics.

\section{References}

Askew, Marc. 1994. Interpreting Bangkok: The Urban Question in Thai Studies. Bangkok: Chulalongkorn University Press.

Bailey, R. W. and Görlach, M., eds. 1982. English as a World Language. Ann Arbor: University of Michigan Press.

Bex, T. and Watts, R. J. 1999. Standard English: The Widening Debate. London: Routledge.

Bhamorabutr, Abha. 1987. The History of Bangkok: Summary of Political and Cultural Events from the Age of Establishment to the Present (Second Edition). Bangkok: Department of Corrections Press.

Cheshire, J., ed. 1991. English Around the World: Sociolinguistic Perspectives. Cambridge: CUIP.

Fishman, J. A., Cooper, R. W. and Conrad, A. W. 1977. The Spread of English. Rowley, MA: Newbury House.

Fishman, J. A., Conrad, A. W. and RubalLopez, A., eds. 1996. Post-imperial English. The Hague: Mouton de Gruyter.

Görlach, M. 1991. More Englishes: New Studies in Varieties of English, 19841988. Amsterdam: John Benjamins.

Görlach, M. 1995. More Englishes: New Studies in Varieties of English, 19881994. Amsterdam: John Benjamins.

Görlach, M., ed. 2002. Still More Englishes. Amsterdam: John Benjamins.

Kachru, B. B., ed. 1982. The Other Tongue: English Across Cultures. Urbana: University of Illinois Press.
Kachru, B. B. 1985. The Alchemy of English: The Spread, Functions, and Models of Non-Native Englishes. Oxford: Pergamon.

Kachru, B. B. 1997. World Englishes and English-using communities. Annual Review of Applied Linguistics 17: 6687.

Landry, R. and Bourhis, R. Y. 1997. Linguistic landscape and ethnolinguistic vitality: An empirical study. Journal of Language and Social Psychology 16.1: 23-49.

MacGregor, L. 2003. The language of shop signs in Tokyo. English Today 19.1: 1823.

McArthur, T. 1998. The English Languages. Cambridge: CUP. 2000. Interanto: The global language of signs. English Today 16.1: $33-43$.

Pennycook, A. 1994. The Cultural Politics of English as an International Language. London: Longman.

Pennycook, A. 1998. English and the Discourse of Colonialism. London: Routledge.

Phillipson, R. 1992. Linguistic Imperialism. Oxford: OUP.

Platt, J., Weber, H. and Ho, M. L. 1984. The New Englishes. London: Routledge.

Schiffman, H. F. 1996. Linguistic Culture and Language Policy. London: Routledge.

Schlick. M. 2003. The English of shop signs in Europe. English Today 19.1: 3-17.

Shohamy, E., Ben-Rafael, E. Amara, M. H., and Trumper-Hecht, N. 2001. Linguistic landscape and multiculturalism: A Jewish-Arab comparative study. Unpublished paper, Tel Aviv University.

Smalley, W.A. 1994. Linguistic Diversity and National Unity: Language Ecology in Thailand. Chicago: University of Chicago.

Smith, L. E., ed. 1983. Reading in English as an International Language. Oxford: Pergamon.

Sternsein, Larry. 1986. Plan of Bangkok BE 2479 (A.D. 1936). Bangkok: Bangkok Municipal Administration. 